\title{
Serum Uric Acid Measurement
}

National Cancer Institute

\section{Source}

National Cancer Institute. Serum Uric Acid Measurement. NCI Thesaurus. Code C61034.

A quantitative measurement of the amount of uric acid present in a sample of serum. 